\title{
What Can Be the Best Corporate Governance Reform?
}

\author{
http://doi.org/10.21272/fmir.3(1).75-91.2019
}

Francesco Di Tommaso

$\mathrm{PhD}$ Economics and Finance University of Rome La Sapienza, Italy

\section{Arturo Gulinelli}

Studio Asse, Iel Ets Legal and Economic Association, Italy

\begin{abstract}
In that paper I start to define that Corporate governance issues have attracted considerable attention not only in Europe but also in UK, and research worldwide in recent decades. Internationally, corporate governance norms have been initiated through a judicious mix of the three available routes: legislation, regulation and self discipline. A world class corporate governance system is where values are as important as rules.Corporate governance is an important part of strategic management that can improve firm performance. Despite its importance, many people are unclear about what corporate governance is precisely. Both managers and investors should understand what corporate governance is and the role that it plays in firms. Being aware of what corporate governance is will allow them to see how it affects their respective businesses. In conclusion good governance practices entail active participation of shareholders in the direct and indirect management of corporation through the Board of Directors and an arrangement of productive checks and balances among shareholders, board of directors and management of corporations. For this reason, every governance model can not fail to take into account appropriate business management models able to identify and classify future events, opportunities and above all potential threats.
\end{abstract}

Keywords: Corporate Governance, Financial Markets.

JEL Classification: M4, M48.

Cite as: Tommaso F. D., Gulinelli Ar. (2019). What Can Be the Best Corporate Governance Reform? Financial Markets, Institutions and Risks, 3(1), 75-91. http://doi.org/10.21272/fmir.3(1).75-91.2019

(C) The Authors, 2019. This article is published with open access at Sumy State University.

\section{Introduction}

1. The purpose of the paper for the Conference is to contribute to the debate of corporate governance models in European transition economies. The paper is structured in the follow's sections 1.1 Corporate Governance Reform Definition and Principles that provides an analysis of the Company's corporate governance framework is based on the following principles Accountability, Fairness, Transparency and Responsibility. 1.2 The General Corporate Governance Structure related with the General meeting with the Shareholders, the Supervisory Board, Revision Commission, and the Corporate Secretary.1.3Good Board Practices characterized by Authority, Size, Terms, Composition and Independences. 1.4 Executive Board with working procedures, Responsibilities and Duties. 1.5 Shareholder Rights in merit of their activities and their contracts. 1.6 Transparency and Information related to the information and communication procedure and 1.7 Financial reporting. The Possible questions of my paper is related if this reform is profitable for the Italian companies and if not where is the possible modification for doing that. In conclusion the Company ensures that beneficial owners of five percent or more of the voting shares are disclosed. Any corporate relations in case of groups of companies are also clearly identifiable and disclosed to the public

\subsection{Corporate Governance Reform Definition and Principles}

I want to intreduce that the Company defines corporate governance as a set of structures and processes for the direction and control of companies, which involves a set of relationships between the Company's shareholders, Supervisory Board, and executive bodies with the purpose of creating long-term shareholder value. It views corporate governance as a means to improve operational efficiency, attract financing at a lower cost, and build a better reputation. It also views a sound system of governance as an important contribution to the rule of law in the Russian Federation, and an important determinant of the role of the Company in a modern economy and society. 
Financial Markets, Institutions and Risks, Volume 3, Issue 1, 2019

ISSN (online) - 2521-1242 ISSN (print) - 2521-1250

The Company Code sets out the Company's corporate governance framework and is based on Russian legislation, the Federal Commission for the Securities Market's Code of Corporate Conduct (FCSM Code), as well as internationally recognized best practices and principles, such as the OECD Principles of Corporate Governance.

The Company's corporate governance framework is based on the following principles:

- Accountability: This Company Code establishes the Company's accountability to all shareholders and guides the Company's Supervisory Board in setting strategy, and guiding and monitoring the Company's management.

- Fairness: The Company obligates itself to protect shareholder rights and ensure the equitable treatment of all shareholders, including minority [and foreign] shareholders. All shareholders are to be granted effective redress for violation of their rights through the Supervisory Board [or a shareholder rights committee, if established].

- Transparency: The Company is to ensure that timely and accurate disclosure is made on all material matters regarding the Company, including the financial situation, performance, ownership, and governance of the Company, in a manner easily accessible to interested parties.

- Responsibility: The Company recognizes the rights of other stakeholders as established by laws and regulations, and encourages co-operation between the Company and stakeholders in creating sustainable and financially sound enterprises.

\subsection{General Governance Structure}

The Company has the following governing and other bodies:

- The General Meeting of Shareholder. The highest governing body of the Company allows the shareholders to participate in the governance of the Company;

- The Supervisory Board is responsible for the strategic direction of the Company, and the guidance and oversight of management; [the Company's Supervisory Board may also establish committees on audit, corporate governance, nominations and remuneration, strategic planning and finance];

- The General Director and the Executive Board carry out the day-to-day management of the Company and implement the strategy set by the Supervisory Board and shareholders;

- The Revision Commission oversees the financial and economic activities of the Company and reports directly to the GMS;

- The Corporate Secretary ensures that the governing bodies follow internal rules and external regulations to facilitate clear communications between the governing bodies, and acts as an adviser to directors and senior executives;

- The Internal Auditor develops and monitors internal control procedures for the business operations of the Company. The Internal Auditor reports directly to the Supervisory Board [through the Audit Committee], and reports administratively to the General Director.

\subsection{Good Board Practices}

The Company views a vigilant, professional, and independent Supervisory Board as essential for good corporate governance. The Supervisory Board cannot substitute for talented professional managers, nor change the economic environment in which the Company operates. It can, however, influence the performance of the Company through its supervision, guidance, and control of management in the interests and for the benefit of the Company's shareholders. Executive bodies also play a crucial role in the governance process. The effective interaction between governing all bodies, and a clear separation of authorities is key to sound corporate governance.

\section{3.1 At the Supervisory Board Level}

a. Authority. The Supervisory Board's scope of authority is set forth in the Company's charter, in conformity with relevant legislation and the recommendations of the FCSM Code.

b. Size. The Supervisory Board [upon the recommendation of its corporate governance committee, if established] recommends the appropriate size of the Supervisory Board. The Supervisory Board's size is fixed 
Financial Markets, Institutions and Risks, Volume 3, Issue 1, 2019 ISSN (online) - 2521-1242 ISSN (print) - 2521-1250

in the Company's charter. Achieving the needed quality and mix-of-skills will be the primary consideration in arriving at the overall number.

c. Election, Term, and Dismissal. Directors are elected for a one-year term. The Company uses cumulative voting to elect its directors.

The Supervisory Board does not believe it is in the best interests of the Company or its shareholders to introduce term limits. Experienced directors, familiar with the Company and the industry in which it operates, are key to providing proper guidance.

The GMS may only dismiss all directors. Grounds for dismissal are included in the Company's charter [or by-law for the Supervisory Board].

d. Composition and Independence. The composition of the Supervisory Board is determined in such a way that combines the representatives of various shareholder groups, including minority shareholders.

The Supervisory Board's composition, competencies, and mix-of-skills are adequate for oversight duties, and the development of the Company's direction and strategy. Each individual director has the experience, knowledge, qualifications, expertise, and integrity necessary to effectively discharge Supervisory Board duties and enhance the Board's ability to serve the long-term interests of the Company and its shareholders. The Supervisory Board has a broad range of expertise that covers the Company's main business, sector, and geographical areas, and includes at least experienced financial experts who are non-executive, independent directors. ${ }^{1}$ A full and complete set of information on the directors' qualifications is set forth and annually reviewed by the Supervisory Board [upon the recommendation of its corporate governance committee] and fixed in the Company's charter or by-laws.

The law prohibits the General Director from being the Chairman of the Supervisory Board. To enhance unbiased oversight, the Company believes that a non-executive director should chair the Supervisory Board.

The Company's Supervisory Board is composed of not more than $25 \%$ of executive directors who are employees of the Company. To ensure the impartiality of decisions and to maintain the balance of interests among various groups of shareholders, $80 \%$ of the Supervisory Board's members are independent directors. The Company defines those directors who have no material relationship with the Company beyond their directorship as independent. The Supervisory Board ascertains which members are to be deemed independent during the first Supervisory Board meeting. Criteria for determining director independence shall be based on the FCSM Code, complemented by other internationally recognized definitions, and specified in the Company's charter and annual report.

The Company recognizes that directors that have served for longer than seven years shall not be considered independent directors.

e. Structure and Committees. The Company has established the following Supervisory Board committees:

- The Audit Committee;

- Board of Director;

- External Staff; and

- Other committees deemed necessary by the Supervisory Board. ${ }^{2}$

All committees have by-laws containing provisions on the scope of authority, competencies, composition, working procedures, as well as the rights and responsibilities of the committee members.

Each committee is to provide provisional consideration of the most important issues that fall within the authority of the Supervisory Board. After each of its meetings, the committee shall report on the meeting to the Supervisory Board.

\footnotetext{
${ }^{1}$ Good practice suggests that the Supervisory Board consist of at least two such persons. Should this not be possible, then the Supervisory Board shall hire an outside, independent adviser.

${ }^{2}$ Other Supervisory Board committees recommended by the FCSM Code and generally-accepted best practices cover areas in which there is an especially large potential for conflicts of interest and the need for independent thought, in particular, the nominations and remuneration committee. Companies may eventually wish to consider adding further committees on corporate governance, strategic planning and finance, shareholder rights, ethics, and/or corporate conflicts resolution. However, companies should be prudent in the establishment of committees. Excessive numbers of committees may be costly, difficult to manage, and may fragment Board deliberations.
} 
Financial Markets, Institutions and Risks, Volume 3, Issue 1, 2019

ISSN (online) - 2521-1242 ISSN (print) - 2521-1250

f. Working Procedures. The Supervisory Board meets according to a fixed schedule, set at the beginning of its term, which enables it to properly discharge its duties. As a rule, the Supervisory Board shall meet at least times a year. ${ }^{1}$

Non-executive directors meet separately from executive members at least once a year.

Detailed procedures for calling and conducting Supervisory Board meetings are defined in the Supervisory Board's by-law. All directors are provided with a concise but comprehensive set of information [by the Corporate Secretary] in a timely manner, concurrently with the notice of the Board meeting, but no less than days before each meeting. ${ }^{2}$ This set of documents is to include: an agenda; minutes of the prior Board meeting; key performance indicators, including relevant financial information prepared by management; and clear recommendations for action.

The Supervisory Board keeps detailed minutes of its meetings that adequately reflect Board discussions, signed by the Chairman [and the Corporate Secretary], and include voting results on an individual basis. The Company keeps transcripts (verbatim reports) of important Board decisions, such as the approval of extraordinary transactions.

g. Self-Evaluation. The Supervisory Board conducts a yearly self-evaluation. This process is to be organized by the corporate governance committee and the results are to be discussed by the full Supervisory Board. Independent consultants may also be invited to assist the Supervisory Board in this process.

h. Training and Access to Advisers. The Company offers an orientation program for new directors on the Company, its business, and other issues that will assist them in discharging their duties. The Company also provides general access to training courses to its directors as a matter of continuous professional education. The Supervisory Board and its committees shall also have the ability to retain independent legal counsel, accounting, or other consultants to advise the Supervisory Board when necessary.

i. Remuneration. The remuneration of non-executive directors is competitive and is comprised of an annual fee (part of which can be paid in the form of shares in lieu of cash), a meeting attendance fee, and an additional fee for the chairmanship of committees or the Supervisory Board itself. The remuneration package shall, however, not jeopardize a director's independence. Executive directors are not paid beyond their executive remuneration package. The Supervisory Board [nominations and remuneration committee] periodically reviews the remuneration paid to directors. All directors sign a contract with the Company. The Company publicly discloses the remuneration of each director on an individual basis.

The Company will not provide personal loans or credits to its directors.

Further, the Company shall not provide stock options to its directors unless approved by the GMS.

j. Duties and Responsibilities. Directors act in good faith, with due care and in the best interests of the Company and all its shareholders and not in the interests of any particular shareholder on the basis of all relevant information. Each director is expected to attend all Supervisory Board and applicable committee meetings.

The Supervisory Board must decide as to whether its directors can hold positions in the governing bodies of other companies. The Company shall not prohibit its directors from serving on other Supervisory Boards. Directors are expected to ensure that other commitments do not interfere in the discharge of their duties.

Directors shall not divulge or use confidential or insider information about the Company.

Directors shall abstain from actions that will or may lead to a conflict of interest with the Company. When such a conflict exists, directors shall disclose information about the conflict of interests to the other directors and shall abstain from voting on such issues.

\subsection{At the Executive Body Level}

The Company understands that the day-to-day management of the Company requires strong leadership from the General Director. It also recognizes the challenge and complexity of running a Company and believes in teamwork, a collective rather than individual approach. The Company has thus established an Executive Board, chaired by the General Director.

\footnotetext{
${ }^{1}$ Good practice suggests that four to ten Supervisory Board meetings per year are sufficient to properly discharge the Board's duties.

${ }^{2}$ Good practice suggests around two weeks.
} 
Financial Markets, Institutions and Risks, Volume 3, Issue 1, 2019 ISSN (online) - 2521-1242 ISSN (print) - 2521-1250

a. Authority. The General Director and the Executive Board carry out the Company's day-to-day management, implementing its goals and objectives, and carrying out its strategy.

b. Size. The General Director [in close cooperation with the nominations and remuneration committee, if established] proposes to the Supervisory Board an appropriate number of Executive Board members. The size of the Executive Board is fixed in the Company's charter upon the recommendation of the Supervisory Board. Achieving the needed quality and mix of executives will be the primary consideration in arriving at the overall number.

c. Election, Term, and Dismissal. The Supervisory Board [or the GMS] elects the General Director for a year term. ${ }^{1}$ The General Director in turn submits proposals for Executive Board membership to the Supervisory Board for approval. Other Executive Board members are appointed for a year term.

The Supervisory Board may dismiss the General Director. The Supervisory Board may also dismiss Executive Board members, upon close coordination with the General Director. Grounds include, among other things, providing false information to the Supervisory Board, willful neglect of his duties and responsibilities, or conviction of a criminal act.

d. Composition. The Executive Board's composition, competencies, and mix-of-skills are suited to the effective and efficient running of the Company's day-to-day operations. Each Executive Board member, including the General Director, has the experience, knowledge, qualifications, and expertise necessary to effectively discharge his duties.

All Executive Board members have the:

- Trust of the Company's shareholders, directors, other managers, and employees;

- Ability to relate to the interests of all shareholders and to make well-reasoned decisions;

- Professional expertise and education to be an effective manager;

- Business experience, knowledge of national issues and trends, and knowledge of the market, products, and competitors; and

- Capacity to translate knowledge and experience into solutions that can be applied to the Company.

e. Working Procedures. The Executive Board meets regularly, and agenda issues are communicated in advance. The working procedures of the Executive Board are specified in the by-laws for the Executive Board.

f. Succession Planning. The Supervisory Board is to adopt a succession plan that outlines how it will effectively deal with the temporary or permanent loss of senior executives. To assist in this process, the General Director is to provide the Supervisory Board with a list of individuals best suited to replace the Company's key executives, including the position of the General Director.

g. Remuneration and Evaluation. The amount of remuneration of the General Director and members of the Executive Board is set by the Supervisory Board, and approved by the GMS. The remuneration shall have a fixed and variable component, and the latter is tied to key performance indicators, in-line with the input into the Company's long-term development and creation of shareholder value. The Company will not provide personal loans or credits to its executive officers.

h. Duties and Responsibilities. The General Director and Executive Board members shall act in good faith and with due care in the best interests of the Company and all its shareholders - and not the interests of a particular shareholder - on the basis of all relevant information.

The General Director and Executive Board members shall abstain from actions that will or may lead to a conflict between their and the Company's interests. When such a conflict exists, members of the executive bodies shall disclose information about the conflict of interests to the Supervisory Board, and shall abstain from deliberating and voting on such issues.

\subsection{Shareholder Rights}

All shareholders have the right to participate in the governance and the profits of the Company. All rights are regulated in the Company's charter and by-laws.

\footnotetext{
${ }^{1}$ Good practice suggests that the Supervisory Board elect the General Director and the other Executive Board members upon the recommendation of the General Director. The IFC's RCGP recommends a term ranging from three to five years, following an initial one-year term.
} 
Financial Markets, Institutions and Risks, Volume 3, Issue 1, 2019

\subsubsection{General Meetings of Shareholders}

The Company has a by-law for the GMS that provides a detailed description of all the procedures for preparing, conducting, and making decisions at the GMS.

a. Preparation. Every shareholder that holds voting shares is entitled to participate and vote during the GMS, and receive advance notification, an agenda, as well as accurate, objective, and timely information sufficient for making an informed decision about the issues to be decided at the GMS. The Company's executive bodies will be responsible for this process, which is to be implemented by the Corporate Secretary.

The Company has a fair and effective procedure for submitting proposals to the agenda of the GMS, including proposals for the nomination of Supervisory Board members. The agenda of the GMS is not changed after the Supervisory Board approves it.

b. Conducting the GMS. The Company takes all the steps necessary to facilitate the participation of shareholders in the GMS and vote on the agenda items.

The venue of the GMS is easily accessible for the majority of shareholders. Registration procedures are convenient and allow for quick and easy admittance to the GMS.

The Company's executive bodies are to help shareholders exercise their voting rights in the event they are unable to physically attend the GMS. The executive bodies will do so by providing shareholders with a power of attorney form, based upon which the shareholder will have an opportunity to instruct his proxy on how to vote on agenda items.

The Company ensures that members of the Supervisory Board, executive bodies, Revision Commission, and External Auditor are present during the GMS to answer questions. Each shareholder has the right to take the floor on matters on the agenda, and submit relevant proposals and questions. The chairman of the GMS conducts the meeting professionally, fairly, and expeditiously.

Voting is conducted by ballot. The Company has effective shareholder voting mechanisms in place (e.g. supermajority voting) to protect minority shareholders against unfair actions, as regulated in its charter and by-law for the GMS. The procedures for counting votes at the GMS are transparent and exclude the possibility of manipulating voting results. The External Registrar of the Company shall also fulfill the functions of the Counting Commission.

c. Results. The voting results and other relevant materials are distributed to shareholders, either at the end of the GMS or very soon after the GMS is held, as well as to the general public by posting them on the Company's internet site and publishing them in the mass media in a timely manner.

\subsubsection{Shareholder Rights Protection}

The Company has a system of registering shareholder complaints and effectively regulating corporate disputes [through the Supervisory Board's shareholder relations committee].

a. Supervisory Board representation. Minority shareholders have on average $50 \%$ identifiable representatives on the Supervisory Board. ${ }^{1}$

b. External Registrar. The Company engages an independent External Registrar to maintain the shareholder register. The Company ensures a reliable and efficient ownership registration system of shares and other securities through the selection and appointment of an independent External Registrar that has proper technical equipment and an excellent reputation.

c. Takeover policy. The Company has a clearly articulated and enforceable policy in place that protects the rights of minority shareholders in special circumstances, such as a change of control.

\subsection{Information Disclosure and Transparency}

Transparency, and timely and accurate information disclosure is a key corporate governance principle for the Company.

\footnotetext{
${ }^{1}$ Good practice suggests that the Supervisory Board's composition reflect the shareholding structure, but that the Supervisory Board have at least one identifiable minority shareholder representative.
} 


\subsubsection{Disclosure Policies and Practices}

The Company discloses and provides easy access to all material information, including the financial situation, performance, ownership, and the governance structure of the Company to shareholders free of charge. The Supervisory Board prepares and approves a by-law on information disclosure and makes it publicly available on the Company's internet site. The Company publishes a comprehensive annual report that includes a corporate governance section, and prepares other reports, such as the prospectus, quarterly reports, and material facts reports. The Company discloses its corporate governance practices, corporate events calendar, and other material information on its website in a timely manner.

The Company takes measures to protect confidential information as defined in its by-law on information disclosure. Any information obtained by the Company's employees and the members of the governing bodies may not be used for their personal benefit.

\section{Literature review}

There are several varieties of corporate governance models in the world. The various models are distinguished according to the degree of capitalism in which the company operates. The liberal model typical of the AngloAmerican states gives priority to the interests of the shareholders. The coordinated model of continental Europe and Japan also recognizes the interests of workers, managers, suppliers, customers and companies. Both models enjoy different competitive advantages, but in different ways. The liberal model encourages total innovation and cost competition, while the coordinated model promotes qualitative innovation and quality competition. In the United States, a company is governed by a Board of Directors, which has the power to choose a CEO (CEO). The CEO has ample powers to run the business on a daily basis, but needs Council approval for certain important maneuvers, such as hiring subordinates, raising finance, acquiring other companies, making capital expansions, or other relevant projects. Other Council duties may include setting corporate policies, decision making, monitoring management performance, or more general control of the company.

The board of directors is appointed by the shareholders, to which they are responsible, but the internal regulations of many companies make it difficult, even for the major shareholders, to exert a certain influence on the composition of the Board; usually, individual shareholders do not have the possibility to choose Board members from a list, but can only approve appointments. In many companies, it happened that incentives were given to the Council, so that the members were under the control of the administrator, who had to control the actions instead. Often, then, members of a Board of Directors are directors of other companies, which some experts see as a conflict of interest.

The corporate governance of a company can be modeled on three schemes:

1. public share company: the company's share capital is divided into a large number of shares, which are listed on regulated markets. The capital then ends up in the hands of an innumerable group of shareholders that make up the company itself. The ordinary assembly is therefore essentially limited to performing the formal functions assigned to it by the various legislations; while substantial decisions are made by a staff of professional managers.

2. consortium company: the decisions made by the management are orchestrated among the various stakeholders of the company. This model has had particular application in Germany and Japan.

3. owner's business: there is only one individual, the entrepreneur, who makes important decisions for company life. The capital is divided in such a way that it is impossible to make a climb to the top of the corporate bodies. This model has had particular application in Italy.

\section{Research Methodology}

The Company keeps records and prepares a full set of financial statements in accordance with Russian Accounting Standards. [In addition, the Company prepares its accounts in accordance with International Financial Reporting Standards (IFRS) [or U.S. GAAP] and discloses these in its regulatory filings, including the annual report, and on the internet.]

Detailed notes accompany financial statements so that the users of the statements can properly interpret the Company's financial performance. A management discussion and analysis (MD\&A), as well as the opinions of the External Auditor and Revision Commission, shall complement all financial information. 


\section{Results}

\subsection{The External Audit}

An External Auditor audits the Company's financial statements. The External Auditor is a publicly recognized independent auditing firm, where independent means independence from the Company, the Company's management, and major shareholders. The Company ensures that the Audit partner is periodically rotated. The remuneration of the auditor is disclosed to shareholders. The External Auditor is selected by the GMS following an open tender and upon the recommendation of the Supervisory Board.

\section{Ownership Structure}

The Company ensures that beneficial owners of five percent or more of the voting shares are disclosed. Any corporate relations in case of groups of companies are also clearly identifiable and disclosed to the public.

\section{Discussion}

In conclusion the governing element of the government of many companies is the board of directors. While managers are selected on the basis of their professional skills, administrators are often hired because they are "in the loop": it is indeed Fortune's news that $80 \%$ of US public companies are administered by no more than 400 people, who they are part of the boards of directors of several dozen companies at the same time. Fortune also reported that the "virus" of predating subscription options, which is a practice for which managers illegally backed the date of options to cash in on more advantageous terms, had spread through a very large network, which would have involved many listed companies. in USA (especially Silicon Valley).

The same problem has recently been explored in Italy by a report focused on network theory. The study shows that even among the boards of directors there is a network, where each person is separated from another only by a limited number of relationships.

In reality, the question goes back to the Corporate America of the seventies; in particular, Myles L. Mace, in a famous empirical research conducted on US listed companies, complained that some directors belonged to six or seven directors at the same time. This elite gave the definition of old boys' club, while the councilors were given the name of ornaments on corporate Christmas trees (literally "decorations on the corporate Christmas tree").

\section{Future research and limitations}

Looking forward for some Italian groups benefit from special control systems, allowed by Italian legislation, but not in most other countries. These systems are characterized by multiple cascading holdings, in which a holding company, often a financial company (therefore without an industrial or mercantile business), controls another company. The controlled company, in turn, controls another company placed under it, which can control other companies, etc.

Generally, control is maintained with the minimum necessary to obtain the absolute majority ( $51 \%$ of capital), which qualifies the subsidiary as a "subsidiary". The structured system takes the name of "pyramid group", or "stock pyramiding", or "financial leverage"; or, more simply, "Chinese boxes". In the Italian model, often the company at the head of the pyramid is a limited partnership for shares, or otherwise difficult to acquire from the outside. This is to protect the ownership of the holding company, which in these cases almost always leads to a family of entrepreneurs. This company then takes the nickname of "safe company" (or "family safe").

In the future the companies below are obviously in the form of a joint-stock company. The greater the number of companies in the pyramid, the lower the risk to which the owner of the parent is subjected. In fact some of the companies can be listed on the stock exchange; obtaining more debt capital from the market, therefore, the owner can limit the amount of own resources invested in the group. It then happens that minority shareholders are so many (and in some cases hold shares without voting rights) that they are strongly disincentive to participate in the meetings. As a result, the owner obtains economic control with an incredibly smaller investment than necessary (to achieve absolute control). This is a "reduction" mechanism of the quota necessary for the control of a company.

Arithmetic example: if to control the ALFA SPA (for example a large industrial company) $51 \%$ of the shares are required, the controlling shareholder, sig. Rossi, can give this $51 \%$ in a new BETA SPA (the first "Chinese box") whose sole purpose is to control the ALFA SPA, keeping only $51 \%$ of the shares in the new BETA SPA and selling the others to cash out liquid assets. In this way Mr. Rossi directly controlling the new BETA SPA, 
also indirectly controls the ALFA SPA, which is what really interests him, but in this way, ie holding $51 \%$ of $51 \%$, in fact only $26 \%$ of SPA capital ALFA, the just invest, and risk, just a little more than half the capital that would be necessary if you want to control the ALFA SPA directly ie without the "Chinese box". If Mr. Rossi wanted to risk even less capital, always without losing control of the ALFA SPA, he just has to insert in the control chain a second "Chinese box", the GAMMA SPA and repeat the operation already done with the first "Chinese box". One of the main criticisms of this system of corporate governance is that it encourages the irresponsibility of entrepreneurs, allowing them to make important decisions about companies in which they have invested relatively modest capital.

\section{Research Questions by Arturo Gulinelli (Studio Asse)}

What are the future challenges and questions to which the organization of the corporate governance model (hereinafter referred to as $\mathrm{CG}$ ) will have to respond?

\section{1) What kind of governance for the future is the shareholder or the stakeholder model?}

It's been about 50 years since the vision, which we can say wrong and that was later retracted, with which the nobel for the economy Milton Friedman, theorized in a famous article on the NYT that the only social responsibility of the companies is to make profits (The Social Responsibility of Business is to Increase its Profits - New York Times Magazine 1970); it was a well-represented synthesis and defense of the shareholders theory.

It is not the task of this work to specify and analyze the theoretical structure of the two governance models; which are widely debated and commented on by various economists for decades. The point is to understand which of the two models can functionally ensure greater stability for companies.

Already from a mere defining point of view, the shareholder model makes us understand that we are facing a CG system, oriented to protect the interests of shareholders and consequently to maximize the profit to be distributed.

Of the finance model it can be said that such a management approach could incorporate a possible defect or better an absence of specification. What profit do we talk about? The residue for shareholders? The added value to be distributed to multiple subjects? Is there a question of short-term or medium-long term profit? The distinction is not trivial.

For example, if we take the annual economic result, we measure ourselves with the return on equity, which is a concept at the end of the period and refers to the profitability of risk capital. We are in an area of business administration where the principle of efficiency comes into play, which allows us to achieve the best result with the least use of resources. Cost control in such a context encourages the board and the management to adopt organizational and management models that reason in short terms.

On the other hand, particularly in the current production contexts in which the company is confronted with a strong variability of demand, the challenge is to focus not on cost reduction - therefore on price - but on the best process and product mix, to increase the value of the company's capital, moving from the equity side to the invested capital - that is, from the equity perspective we move to that of investments - and at the same time to the idea of efficiency we add that of effectiveness.

In fact, the economic result for the period is not sufficient to ensure long-term profitability, because the profit - and therefore the efficiency of management - although necessary is continually questioned by the changed operating conditions in which the company operates and by the variability of all factors of production, not just financial capital. Without investment in research and development and without investment in human capital, the stability of every business model would be compromised over the medium term.

On the other hand, particularly in the current production contexts in which the company is confronted with a strong variability of demand, the challenge is to focus not on cost reduction - therefore on price - but on the best process and product mix, to increase the value of the company's capital, moving from the equity side to the invested capital - that is, from the equity perspective we move to that of investments - and at the same time to the idea of efficiency we add that of effectiveness.

In fact, the economic result for the period is not sufficient to ensure long-term profitability, because the profit - and therefore the efficiency of management - although necessary is continually questioned by the changed operating conditions in which the company operates and by the variability of all factors of production, not just 
Financial Markets, Institutions and Risks, Volume 3, Issue 1, 2019

ISSN (online) - 2521-1242 ISSN (print) - 2521-1250

financial capital. Without investment in research and development and without investment in human capital, the stability of every business model would be compromised over the medium term.

An institution is really competitive if its government is able to manage and increase the value of its distinctive resources and competences, preserving them over time. Every action that goes in the sense of ensuring greater economic value and that takes into account only short-term profit is a management behavior that undermines the existence of every economic entity.

Another annotation that differentiates the two CG models is the information asymmetry that exists between agents and stakeholders; it is clear that the one who acts has complete information and is the board and the management who choose which direction to follow and which choices to make. Therefore, there is a passive position in terms of time that distinguishes the role of some stakeholders, who learn the economic results achieved and certain company policies only ex post.

In fact it is what has happened in many companies during the last years: in critical conditions, the creation of value for the majority of stakeholders has often been penalized, opting to confer advantages to the top management (shareholders and managers - the latter with compensation and stock options, shareholders with dividends and purchases of treasury shares) relying on opaque management and communication techniques and on the lack of involvement of external or weaker subjects. And so a trade-off is generated, the governance that is bent to the logic of the formation of non-transparent decisions that generate conflict rather than cooperation.

But is the success of the companies due to the shareholders giving risk capital, or does it often depend on the commitment and capacity of human capital, on the good services and products and on the collaboration of suppliers and on good relations with customers?

It is clear that the success of companies depends not only on the initial endowment of capital provided by the shareholders or on the good management of the management, but also and essentially on a series of conditions and contexts that require cooperation.

The business crises and frauds (Enron, Worldcom, Parmalat etc) that have characterized the last decades have certainly highlighted a deficit of vigilance and risk prevention, revealing an irremediable deficit of some CG models.

The great convergence: even the most orthodox authors are convinced that it is not the profit and its distribution that is the sole mission of the enterprises, thus admitting the existence of non-economic constraints to their actions.

Social responsibility favors company policies that comply with ethical principles that can:

$>$ reduce the reputational risk deriving from violations of regulations or environmental damage;

$>$ create a climate of trust that increases the motivation and sense of belonging of employees and suppliers and customers;

$>$ attenuates the conflict with the external control and surveillance organizations and with the community in general (trade unions, external surveillance bodies, territory, families, public bodies).

Reputation is certainly one of the drivers of greatest impact for 21 st century companies. The information circulates rapidly and the bad reputation that may derive from questionable, opportunistic or culpable management events that imply social and environmental repercussions have effects on the sales and financial soundness of the companies.

Certainly, the adoption of CG models inspired by the stakeholder theory is not sufficient to ward off reprehensible business practices and criminal behavior; the diesel gate case that hit Volkswagen. The German brand has been awarded many awards in terms of corporate social responsibility by winning prestigious awards (the Gold Medal Award for Sustainable Development awarded by the non-profit World Environment Center). The diesel gate that involved Volkwagen and other automotive companies does not help to understand how CSR really works and whether its implementation responds to mere marketing techniques (so-called greenwashing) or is really felt by companies.

\section{How can CSR push corporate performance?}

The reputation is certainly one of the variables that in recent years is increasingly studied and looked after by investors but also by consumers and buyers. 
Consumers have confirmed in recent years, in many questionnaires and interviews that have affected them, that they have developed a strong sensitivity towards the issues of social and environmental sustainability and preferences and consumption choices in purchasing decisions are influenced by reputational issues. This is why companies must pay attention to the way they act and operate; because running into reputational problems can jeopardize profits.

Even institutional investors are increasingly attentive to these logics; moreover, a company that incurs a liability for environmental damage or for tax cases in terms of evasion or avoidance, could suffer severe setbacks and large losses.

Recent surveys say that almost two thirds of consumers make purchase choices by following product reviews and that among the characteristics sought in the products there are variables (in addition to price) such as: the healthiness of the product, the construction materials, the resulting effects from its consumption; last but not least information is acquired on the company that sells and markets products. In many cases, consumers have responded, over $65 \%$ of respondents, who would be willing to pay more for an asset that has been created according to processes that integrate and respect ethical behavior.

Employees too often try to understand security and labor rights policies when choosing their employer. A company of this kind is more attractive in the personnel selection phase.

Transparency is also a value perceived by consumers and investors, with increasing attention. For example, a communication that integrates financial and non-financial data is used more and more frequently by companies to communicate their behaviors and their performance and not only in the economic and financial field.

Can a good CG influence the economic performance of a company? If you are through which drivers?

The scientific literature is conflicting on this aspect; there are studies that highlight the lack of correlation between economic performance and CG practices (see Bauer et al of 2004), while other authors believe that a CG system can have positive effects on the economic market valuation of a listed company (Renders et al., 2010).

Since there is no univocal address it is difficult to reach a clear position; it is, however, clear that a CG system based on long-term value management and that is committed to promoting respect for the rights of all stakeholders may, more than other business management systems, reduce risks and guarantee, if not the achievement of better economic performance, certainly a conservation of corporate assets over time.

Among the most relevant drivers that a good CG system can introduce in companies' decision-making practices is likely to be the attention of managers and long-term shareholders.

In fact, in the pre-crisis years, many private companies showed clear strategic management limits, especially in the choice of investments and dividend policies, both driven and voted on short-term logic.

The agency relationship and the information asymmetries, which represent the most important problems in the relationship between shareholders and management, have led in the last thirty years, especially large companies, to a strong expansion of policies to reduce investments, especially those medium-long term, to which dividend distribution and repurchase of shares have been preferred to push short-term prices.

Strategies of this kind undermine, however, the economic flows of the future. Preferring the distribution of dividends instead of investments in research and development can make the company attractive in the eyes of speculative investors but certainly not institutional ones.

In this way, capital is collected but capital is not stable and will soon move towards more profitable returns.

Companies, on the other hand, depend on the income flows and cash flows that they will achieve in the future and these depend on productive and innovative investments.

Interesting analysis conducted by Andrew Haldane (chief economist of the Bank of England) who along with other scholars on 624 companies listed in part on the British FTSE index and partly on the S \& P index. The period covered by the study covers the years from 1980 to 2009. The model used by Haldane made it possible to identify the short-termism policies used by the target companies, by measuring the applied discount rate which was generally much higher than the real one. A high discount rate reduces the net present value of future cash flows by making an investment less attractive and cost-effective (the cost of investment exceeds the NPV and the investment is discarded). 
Financial Markets, Institutions and Risks, Volume 3, Issue 1, 2019

ISSN (online) - 2521-1242 ISSN (print) - 2521-1250

The author goes on to comment on the studies done by other economists and concludes that in Great Britain as in the USA, the two countries that have highly developed financial markets, the lack of investment in research and development are very large and that, in the nineties about half of the first two hundred companies in the world that invested in research and development were just American or British, in 2009 the share of Anglo-Saxon companies had fallen by over $18 \%$. The reduction in investments leads to a reduction in the ratio between capital and production, a reduction of production capacity, therefore of national production and therefore of aggregate demand, with evident macroeconomic effects.

The short-term strategies are not likely to undermine, therefore, only the solvency of companies in the long term but also the economic growth and competitiveness of the economy of the nation states.

\section{2) Do we need to intensify risk forecasting and management models to govern market turbulence?}

The 2007-2008 crisis was more intense for companies than the one of '29 because it was a deep crisis and that it found an integrated financial and economic system at the global level and then spread rapidly from the United States to Europe. and then to developing countries.

The systemic integration of the markets is therefore a first new "variable" difficult to predict, which has escaped the general equilibrium macroeconomic models (the DSGE models), as well as the models used by the rating companies to evaluate the large companies; both its micro and its macro models can not make predictions that take into account a systemic view and the interactions between variables and between flows and stocks that can derive from highly integrated markets.

Even a marketing guru like Philp Kotler decided to confront himself in 2010 with the topic of the turbulence and discontinuity of the economic environment in which companies operate (Chaotics - management and marketing in the turbulence era P. Kotler and JA Caslione 2010 edition September 2009 Sperling \& Kupfer).

The system suggested by the two scholars is the so-called "Chaotics Management System", a method of analysis and business management that would allow companies to grow (ed and survive) in periods of chaos.

Nothing innovative that companies do not, perhaps implicitly always, that is:

. create pre-alarm systems that identify potential causes of turbulence in the reference markets;

. create key scenarios to analyze and respond to the turmoil;

. verify and test the strategies according to their own resistance and ability to react to risks.

And the point is not just to predict the possible future crises but also the technological changes, which are ever faster and more sudden, which displace businesses with their business models.

Even without resorting to the great crisis of 2007, history is full of companies that even if they are leaders of their market have been overwhelmed by unforeseen and difficult to foreseen technological innovations.

Therefore, careful governance can not fail to take due account of the creation of precise risk assessment and management systems.

We do not want to elaborate on the various models of existing ERM (enterprise risk management), rather the purpose of these notes is to stimulate debate on the variables and determinants that must be considered as sources of risk.

\section{What role should corporate governance (hereinafter referred to as CG) have in risk management?}

The corporate governance system, above all, in the economic crisis has shown the limit of having concentrated too often on the economic performances and on the profitability (value of shares) in the short term, while it should have focused on creating long-term corporate value.

The corporate governance system, above all, in the economic crisis has shown the limit of having concentrated too often on the economic performances and on the profitability (value of shares) in the short term, while it should have focused on creating long-term corporate value.

Clearly the correlation between good governance and economic results is not easy to prove empirically. It is certain, however, that an effective control system can mitigate risks and ensure better results and profitability in the $\mathrm{m} / 1$ term.

In which areas must the CG operate to improve company management and reduce risks? 
Basically, there are four macro areas to be monitored and managed:

$>$ Ensure the stability of the company's property;

$>$ Protection of minorities;

$>$ Manage the composition and operation of the board and the related salaries;

$>$ To oversee non-financial and financial risks.

\section{Is the stability of the company a value?}

For family businesses (in Italy about $80 \%$ of companies), even if listed, it is necessary to ensure generational transitions that are able to maintain stable the structure that controls the company and decides investments and strategic policies. Intergenerational conflicts or conflicts with new shareholders or investors could change the context of reference and change the choices that have ensured historical development and profitability.

Family pacts, shareholders' agreements and voting agreements are interesting and appropriate tools to monitor the choices and critical steps of each company; at the same time allowing the protection of minority shareholders' shares can allow the entry of new members and reduce the litigation that may arise as a result of the development of new projects or the planning of extraordinary operations.

The protection of minorities by appointing counselors increases the independence component and reduces risks?

The protection of minorities is certainly an element of absolute importance to ensure a company management that increases involvement and reduces conflicts between members.

This need is all the more appropriate in a country like ours where companies have a high concentration of concentrated shareholders; just think that companies with a widespread shareholding are few.

Among the companies listed on the Italian Stock Exchange, the controlling share held by a reference shareholder is close to $40 \%$ and only a quarter $(25 \%)$ of the companies have members in the board expressed by minority shareholders.

The directors appointed by the minorities generally manage to ensure greater control over the strategic initiatives taken by the directors who report to the majority, this independence allows for greater control over the work of the CDA.

The minority shareholder is generally less encouraged to speculative investments and projects (especially institutional investors such as banks and finance companies) from a medium to long-term perspective, with particular attention to the overall sustainability of the business.

Managing the composition and functioning of the board and the related salaries is a stimulus to the contraction of the risk?

The composition of the board has a decisive impact on the policies that the company can adopt. For example, the presence of figures with diversified experience and professionalism can help to better understand the environment in which the company operates and improve the level of internal managerial culture.

The policy of introducing clauses providing long-term variable incentives (LTI long term incentive) is also valid.

It is important to follow some rules when negotiating the fee:

$>$ introduce an adequate number of performance indicators with their respective weights (easily measurable indicators that pay attention to both profitability and cash flow generation, as well as sustainability), avoiding to dwell on a single indicator such as the value of shares;

$>$ remove from the quantitative performance indicators the effect that may derive from particular phases of favorable or speculative economic contingency that may determine the overvaluation of some results;

$>$ establish elements of qualitative performance that pay attention to the company climate, to social and environmental sustainability, to reputation.

It is important to integrate plans that guarantee the continuity of management of industrial programs by ensuring the best and quickest succession of both the board members and top management figures; this practice is still little used in Italy, just consider that only about $20 \%$ of listed companies have prepared succession plans. 
Financial Markets, Institutions and Risks, Volume 3, Issue 1, 2019

\section{How to monitor non-financial and financial risks?}

Business risk management is inherent in operating in contexts in which financial and non-financial forecasts are often difficult to interpret. If we overcome the neoclassical epistemological approach of market perfection and therefore recognize that contracts are incomplete and markets are imperfect we can well understand how firms often find themselves operating in conditions of uncertainty having to make estimates and analyzes of variables and conditions that influence the development and the occurrence of which is uncertain.

The uncertainty in the planning phase can lead to the adoption of wrong choices in the economic field and a wrong investment or a large loss on credits or the bankruptcy of a customer for a large order are situations that can lead the company to failure.

The costs of disruption are, certainly, higher than those to be borne in the planning stage and for this reason that companies already starting from the '70s have begun to give importance to risk forecasting systems (risk management).

The crisis of 2008 has highlighted, where it was needed, that the systemic interdependence of the markets can also undermine companies that have not directly taken speculative risks, perhaps simply because these companies were too exposed to risky counterparts (risk counterparty). In Italy, some studies carried out with reference to the real estate market, particularly affected by the crisis, as the credit risk deriving from the default of the counterparty rose from about $12 \%$ in 2007 to $23 \%$ in 2012 (almost doubled).

An integrated approach to risk management is Enterprise Risk Management (ERM below).

An ERM system consists in mapping the internal system to the company and in identifying the risk areas, in defining the objectives to be achieved with the model. At this point the system will identify events, measure them, assign a risk class that allows their evaluation. For each degree of risk associated with a given event, response and protection actions will correspond. The event thus identified and treated will be monitored to verify the eventual event and the type of consequences in the patrimonial and economic field.

Medium-sized companies that must monitor financial risks (credit, foreign exchange) and operational risks have the advantage of introducing ERM systems because the cost of bearing a risk that is not "hedged" may be higher than the cost that derives from implementation and model management.

SMEs can evaluate the adoption of simplified approaches that however go in the direction of pushing the entrepreneur to manage the most significant risks. The structure and the organizational models of the new article 2086 of the civil code. The reform of insolvency proceedings led the current executive to adopt a comprehensive reform of bankruptcy legislation with the adoption of a special code of the business crisis.

Among the innovations introduced by the new code, we find the change made to article 2086 of the civil code from article 374 of the crisis code. The second paragraph is established which has the following content: "The entrepreneur, who works in a corporate or collective form, has the duty to establish an organizational, administrative and accounting structure appropriate to the nature and size of the company, also in operation. the timely detection of the company's crisis and the loss of business continuity, as well as the timely activation of the adoption and implementation of one of the tools provided for by the regulation to overcome the crisis and the recovery of business continuity".

The underlining of the anchor is to show that the amendment of Article 2086 of the Civil Code will not only deal with procedures to prevent the crisis, but could mean the need for entrepreneurs, each according to their size and structure, to use organizational structures and models and tools that ensure a correct and efficient management that allows to ensure the emergence of any economic and financial problems.

Moreover, its placement within Article 2086 could be interpreted as being aimed at all entrepreneurs, both collective and individual, and not only commercial but also agricultural ones.

The code of the business crisis that has yet to be published in the OJ will have time to come into force; at the moment, the legislation still seems to want to widen the scope, previously envisaged for the spa alone, on the subject of good administrative and accounting governance, always in order to prevent risks (in this case the crisis). 


\section{Conclusion}

\section{Internal Audit and Control}

a. The Revision Commission. The Company's Revision Commission is to meet at least $20 \%$ times a year to carry out its duties as specified by law and its by-laws. The Revision Commission shall consist of independent members, of which at least $17 \%$ members are experienced financial experts. Its scope of authority and activity goes beyond legislative requirements. ${ }^{1}$

b. The Internal Auditor. The Company has an Internal Auditor [or office of the Internal Auditor that is responsible for the daily internal control of the Company's finances and operations. The Internal Auditor is staffed by a highly respected and reputable person[s], and reports to the Supervisory Board [or Audit Committee] functionally and to the General Director administratively. ${ }^{2}$ The Internal Auditor's authority, composition, working procedures, and other relevant matters are regulated in its by-law.

c. The Supervisory Board's Audit Committee. The Audit Committee is to focus on three key areas: financial reporting, risk management, and internal and external audit. This committee is to be chaired by an independent director and composed of non-executive directors, each of which is recognized for his or her financial literacy. Its exact authority, composition, working procedures, and other relevant matters are regulated in its by-laws.

\section{References}

1. Special report: corporate governance, investors fight back. (2004, May17). Business Week. Available at: https://www.sec.gov/Archives/edgar/data/1018724/000119312516530747/d78603ddef14a.htm

2. Alrabba, H. M. (2016). Measuring the impact of code of ethics on the quality of auditors' professional judgment. Journal of Governance and Regulation, 5(4), 54-60. Available at: https://doi.org/10.22495/jgr_v5_i4_p4

3. Baker, M. (2006, March 29). Private communication. Business in the Community.

4. Brewster, D. (2004, August 9). CalPERS wave-making brings flak. Financial Times Fund Management.

5. Butz, C. (2003). Decomposing SRI Performance, Geneva: Pictet \& Cie.

6. Cadbury Committee (1992). Report of the Committee on the Financial Aspects of Corporate Governance. Available at: http://www.ecgi.org/ codes/documents/cadbury.pdf

7. Collins, J. (2001). Good to great. London: Random House Business. Available at: https://www.penguin.co.uk/books/104/1045846/good-to-great/ 9780712676090.html

8. Collins, J., \& Porras, J. (1994). Built to last. New York: Harper Business. Available at: https://www.amazon.com/Built-Last-Successful-Visionary- Essentials/dp/0060516402

9. Conference Board (2003). Commission on public trust and private enterprise: Findings and recommendations. Available at: https://www.conference- board.org/pdf_free/SR-03-04-ES.pdf

10. Doyle, J. L., Colley, J., Stettinius, W., \& Logan, G. (2005). What Is Corporate Governance? New York: McGraw-Hill.

11. El Nashar, T. (2016). The probable effect of integrated reporting on audit quality. Journal of Governance and Regulation, 5(2), 50-58. Available at: http://doi.org/ 10.22495/jgr_v5_i2_p6

12. Eun, C. S., Resnick, B. G., \& Sabherwal, S. (2004). International Finance. Wall Street Journal. Aril 9, 1996. Available at: https://link.springer.com/content/pdf/bbm\%3A978-3-030-02792-6\%2F1.pdf.

13. Ferri Di Fabrizio, L. (2017). The pattern of fraudulent accounting: Ethics, external auditing and internal whistle-blowing process. Journal of Governance and Regulation, 6(1), Available at: 12-25. http://doi.org/10.22495/jgr_v6_i1_p2

\footnotetext{
${ }^{1}$ Supervisory Board audit committees are becoming increasingly common internationally. Good practice suggests that the Company strengthen the role of the Supervisory Board's Audit Committee and make sure that it complements the functions of the Revision Commission. Good practice suggests that the Revision Commission meet at least four times per year, and that it be composed of at least one financially literate member.

${ }^{2}$ Good practice suggests that the Internal Auditor be a member of the Institute of Internal Auditors (see also: http://www.iia-ru.ru).
} 
Financial Markets, Institutions and Risks, Volume 3, Issue 1, 2019

ISSN (online) - 2521-1242 ISSN (print) - 2521-1250

14. Feten, A., \& Salma, D.-A. (2015). The use of international standards in ethics education in the Tunisian audit context. Journal of Governance and Regulation, 4(4-4), 499-506. Available at: http://doi.org/10.22495/jgr_v4_i4_c4_p7

15. Gimbel, F. (2004, April 19). US activist launches hedge fund (for corporate governance). FT Fund Management. Available at: http://nylawyer.nylj.com/adgifs/decisions/120607hedgefund1.pdf

16. Gompers, P., Ishii, J., \& Metrick, A. (2001). Corporate governance and equity prices (NBER Working Paper No. 8449).

17. Habbash, M. (2012). Earnings management, audit committee effectiveness and the role of blockholders ownership: Evidence from UK large firms. Journal of Governance and Regulation, 1(4-1), 100116. Available at: http://doi.org/ 10.22495/jgr_v1_i4_c1_p1

18. ICGN (2002). Cross border proxy voting, case studies from the 2002 proxy voting season. London: International Corporate Governance Network.

19. IF AC (2003). Rebuilding public confidence in financial reporting: An international perspective. New York: International Federation of Accountants.

20. IFAC (2004). Enterprise governance: Getting the balance right. New York: International Federation of Accountants.

21. Kandemir, H. K. (2016). Auditing versus consultancy: a critique of the EU law reforms on the new form of auditing. Journal of Governance and Regulation, 5(3), 90-97. Available at: http://doi.org/10.22495/jgr_v5_i3_p8

22. Krauß, P., \& Zülch, H. (2013). The relation of auditor tenure to audit quality: Empirical evidence from the German audit market. Journal of Governance and Regulation, 2(3), 27-43. Available at: http://doi.org/10.22495/jgr_v2_i3_p2

23. Larcker, D., Richardson, S., \& Tuna, I. (2005, May 2). Ratings add fire to the governance debate. FT Mastering Corporate Governance. Available at: https://aaapubs.org/doi/pdf/10.2308/accr.2007.82.4.963

24. Ledimo, O., \& Martins, N. (2014). An audit of employee commitment to enable leaders to manage organizational talent. Journal of Governance and Regulation, 3(3-1), 128-133. Available at: http://doi.org/10.22495/jgr_v3_i3_c1_p6

25. Los Angeles Times (2004, April 3). Ex-exec tells of Adelphia fraud'. Available at: https://www.jstor.org/stable/29789727?seq=1\#page_scan_tab_contents

26. McKinsey \& Company (2002). Global investor opinion survey on corporate governance, London, McKinsey \& Company.Standard \& Poor's Governance Services (2002). Corporate Governance Scores: Criteria, Methodology and Definitions, New York, Standard and Poor's. Available at: https://www.mckinsey.com/client_service/corporate_finance/latest_thinking/mckinsey_on_finance/ /media/ DD152F22B7CC4B099913E114ĀC5558FB.ashx

27. Monks, R. A. G., \& Minow, N. (2015). Corporate Governance (5thed.). Chichester, The UK: John Wiley \& Sons Ltd. http://doi.org/10.1002/ 9781119207238

28. Murase, H., Numata, S., \& Takeda, F. (2013). [Conference issue]. Journal of Governance and Regulation, 2(3), 7-23. http://doi.org/10.22495/jgr_v2_i3_p1

29. Tayan, B. \& Larcker, D. F. (2015). Corporate governance matters: A closer look at organizational choices (2nd ed.). New Jersey: Pearson Education. Available at: https://www.amazon.com/CorporateGovernance-Matters- Organizational-Consequences/dp/0134031563

30. Tricker, P. I. (2017). Corporate governance: principles, policies, and practices. Oxford, the UK: Oxford University Press. Available at: https://global.oup.com/ukhe/product/corporate-governance9780198702757? cc=ua\&lang=en\&

31. Unctad (2003). Case study on corporate governance disclosures in the United States of America (Report No. TD/B/Com.2/ISAR/19/). Available at: https://unctad.org/en/docs/c2isar19_en.pdf

32. Unctad (2005). 2005 Review of the implementation status of corporate governance disclosures (Report No. TD/B/COM.2/ISAR/CRP.1). 
33. Velte, P. \& Stiglbauer, M. (2012). Impact of auditor and audit firm rotation on accounting and audit quality: A critical analysis of the EC regulation draft. Journal of Governance and Regulation, 1(3), 7-13. http://doi.org/ 10.22495/jgr_v1_i3_p1

34. Velte, P., \& Eulerich, M. (2014). Increased auditor independence by external rotation and separating audit and non-audit duties? - A note on the European audit regulation. Journal of Governance and Regulation, 3(2), 53-62. http://doi.org/10.22495/jgr_v3_i2_p5

35. Webley, S., \& More, E. (2003). Does business ethics pay: Ethics and financial performance. London: Institute of Business Ethics. Available at: https://www.ibe.org.uk/userfiles/doesbusethicpaysumm.pdf

36. Wilkinson, N., \& Coetzee, P. (2015). Internal audit assurance or consulting services rendered on governance: How does one decide? Journal of Governance and Regulation, 4(1-2), 186-200. http://doi.org/10.22495/jgr_v4_i1_c2_p3

37. Relazione Assonime "La Corporate Governance in Italia: autodisciplina, remunerazioni e comply-orexplain (anno 2017) del Febbraio 2018. Available at: http:/www.assonime.it/attivitaeditoriale/studi/Pagine/note-e-studi-2-2018.aspx

38. 2017 CSR RepTrak - How to use data to connect CSR and Reputation and be relevant for the business. Available at: https://www.reputationinstitute.com/sites/default/files/pdfs/2017-Italy-CSR-RepTrak.pdf

39. Report on corporate governance of Italian listed companies 2017 - fonte Consob; Available at: http://www.consob.it/web/consob-and-its-activities/rcg2017

40. Zamagni S. (2006). Responsabilità sociale delle imprese e "Democratic Stakeholding", Forlì, Aiccon, WorkingPaper n. 28. Available at: http://www.consob.it/web/consob-and-its-activities/rcg2017

41. Milton Friedman. (1970). The Social Responsibility of Business is to Increase its Profits. New York Times Magazine. Available at: https://www.duo.uio.no/bitstream/handle/10852/38408/ Mertens_Filsosofi_ Master.pdf?

42. Tarantola A. (2011). Il ruolo del risk management per un efficace presidio dei rischi: le lezioni della crisi, Intervento alla CommunityCib - SDA Bocconi, Milano, 10 novembre. Available at: http:/umich.edu/ $\sim$ thecore/doc/Friedman.pdf

43. Amartya K. (1988). Sen Etica ed Economia Editori Laterza. Available at: https://archiviomarini.sp.unipi.it//541/1/Amartya\%20Sen,\%201a\%20filosofia\%20politica\%20(S_\%20Carus)

44. Andrew Haldane. (2016). The costs of short-termism BOE. Available at: https://www.bis.org/review/r171013f.pdf

45. Il codice della crisi di impresa schema di Dlgs del 10/1/2019. Available at: https://www.altalex.com/ documents/news/2018/11/28/codice-crisi-impresa-e-insolvenza 